\title{
On Phillip Brown, Hugh Lauder and David Ashton's The Global Auction: The Broken Promises of Education, Jobs, and Incomes. Oxford/New York, NY, Oxford University Press, 2011
}

Keywords: education, globalization, skills, labor markets, income, inequality JEL classification: 124 education and inequality

\author{
Marius R. Busemeyer* \\ University of Konstanz, Germany \\ *Correspondence: marius.busemeyer@uni-konstanz.de
}

Brown, Lauder and Ashton's Global Auction makes a tremendously important point: promoting education by all means is no cure-all for the negative side effects caused by the ever-intensifying economic globalization. The conventional wisdom so far has been that the effects of globalization in advanced industrial democracies will privilege high-skilled, i.e. college-educated, workers over the low-skilled. As a consequence, the only way out of the low-skills trap would be to promote policies of skill formation for those in the lower half of the skills distribution (Boix, 1998; Crouch et al., 1999).

Brown et al. add a new argument to this debate: the link between labour market risk and skills is not as straightforward and linear as usually assumed. Of course, being low-skilled is associated with a higher risk of being unemployed or working in the low-wage sector. However, and this is the real contribution of Brown et al., having a decent education, for instance a college degree, can no longer be regarded as a sufficient insurance against labour market risk. This claim is based on a simple fact with large scale, but hitherto underestimated, 
implications: the entry of countries such as India and China into the globalized capitalist economy significantly expands the labour market supply not only in low-skilled domains, but also in the middle segment of the skills distribution, i.e. the classical white-collar jobs of the middle class. Although the relative share of the population with higher education credentials in newly industrialized countries might be much smaller than in advanced democracies, there are simply a good deal more Indians and Chinese around. Furthermore, the skills in question-e.g. programming, administrative skills, etc.-are highly portable, so that outsourcing from the advanced to the newly industrialized economies poses even fewer problems than in the case of manufacturing. The consequence of this state of affairs is a new kind of wage competition between the white-collar middle class in advanced industrial democracies and 'well-educated, low-cost workers' (p. 12) in countries such as India and China.

The main message of the book is highly convincing. The empirical evidence brought forward to support the core thesis is more descriptive and anecdotal, rather than founded on hard statistical analyses or minute transcriptions of interviews. Nevertheless, the sheer quantity and breadth of interviews conducted is impressive [the authors claim to have talked to 'around 200 corporate executives and national policy makers in seven countries' (p. vii)]. The upside of the chosen empirical strategy is that it makes the book accessible for a broad audience beyond the academic ivory tower.

Despite this generally positive assessment, I would argue that there are several points in the book which could and should have been developed further in order to make the case more convincing: the case of the USA in comparison with other countries, the role of the state and politics, the importance of vocational education and training and, finally, the outlook on what is to be done. I am going to briefly talk about each of these in the following.

\section{The USA and the rest}

Clearly, the book is directed at an American audience (which is somewhat surprising, given that the authors are based in the UK). The topic of the broken promise of the American Dream is a recurring leitmotif (see especially Chap. 10). This focus resonates very strongly with other recently published books catering to rising middle-class anxiety in the USA [e.g. Hacker's (2006) Great Risk Shift]. Faced with exploding health care costs, a sluggish labour market, stagnating wages as well as a defunct and polarized political system unable to effect real policy change, it is quite understandable why the American middle class is in need of reassurance and consolation. With regard to higher education, middle-class Americans may feel betrayed like former citizens of the German Democratic Republic who had saved and waited for their own 
automobile for 20 years only to find out that Western Germans could supply better and less expensive models in much shorter time.

From an analytical perspective, the book's focus on the USA and Britain is unfortunate, however. Thus, the authors remain ambiguous about whether their diagnosis applies to the American patient only or whether it is a phenomenon to be observed in other advanced industrial democracies as well. Implicitly, the authors suggest the latter because they do not talk about the impact of different socio-economic institutions on labour market outcomes in a systematic way. Comparing the USA with other countries, however, reveals that other countries have been quite successful in establishing high-skill societies, as two of the authors themselves demonstrated in an influential book a couple of years ago (Brown et al., 2001).

\section{Labour markets, skills and politics}

The second point I want to make relates to the previous one. One crucial difference between the USA and other countries pertains to the role of the state. In this respect, Brown et al.'s critique of the work of Goldin and Katz (2008) is highly welcome. The theory of skill-biased technological change (SBTC) developed in this work explains increasing levels of socio-economic inequality with changes in the relative supply and demand for high-skill labour. From the perspective of SBTC, rising inequality is a consequence of the fact that the supply of college-educated labour cannot keep up with increased demand. Hence, the wage premium of college education increases, leading to higher levels of inequality. In the Goldin-Katz framework, inequality seems to be an inadvertent, but irrevocable, side effect of the anonymous forces at work on labour markets. Empirically, however, it can be shown that differences in the institutional set-up of the political economy and in the character of public policies do have strong effects on the supply side of skill formation systems (Busemeyer and Iversen, 2012), leading to very different patterns of stratification and inequality.

Brown et al. concur with this perspective when criticizing Goldin and Katz for their failure 'to consider the wider employment, organization, and political context that determine the way technology is used and rewarded in the workplace' (p. 127). However, this point could have been developed much further, e.g. by including more comparisons across countries.

Even if the focus on the USA is maintained, the analysis could have taken the political dimension more seriously. Brown et al. provide a very sophisticated description and analysis of the problem, but they do not explain why nothing is being done about it. It can be assumed that, at least in very basic terms, voters acknowledge the problem of a significant worsening of the ratio between the costs and benefits of college education. But why is the cost of tuition rising 
anyway? Why do we not see significant increases in public funding for higher education, e.g. in the form of a new version of the GI Bill? Clearly, the specific character of American political institutions and culture needs to be mentioned here. Other recent contributions to the American debate on inequality such as Hacker and Pierson's (2010) Winner-Take-All Politics go much further in integrating politics into the story than Brown et al.

\section{The transferability of skills}

The transferability of skills is a crucial component in the argument developed by Brown et al. The problem of wage competition in the middle segment of the skills distribution is largely caused by the fact that the kinds of services provided by white-collar, mid-level jobs can easily be transferred to other countries. In part, this is a consequence of technological developments in information and communication technologies, which allow for the instantaneous exchange of information across continents. However, another part of the story is the fact that the skills that are required to perform these tasks can also be transferred quite easily from one context to another. The conventional perspective of human capital theory (Becker, 1993) is that workers with general skills can employ their skills productively in a large number of firms. Hence, workers with specific skills are believed to be more vulnerable to labour market fluctuations and, according to the influential Varieties of Capitalism argument, need social insurance to be willing to invest in these skills (Estevez-Abe et al., 2001).

Brown et al.'s argument, although this is not necessarily acknowledged by the authors themselves, adds to the recent critical debates about the meaning of asset specificity in skills (Busemeyer, 2009; Emmenegger, 2009; Streeck, 2012). For one, the transferability of skills might allow workers to move more easily between firms, jobs and economic sectors. However, transferability of skills also means that workers can be replaced more easily. At the same time, asset specificity in skills increases the mutual dependence between employers and employees. Workers with specific skills may face higher labour market risks, on the one hand, but on the other, employers cannot replace these workers without losing their share in joint human capital investments (Emmenegger, 2009), which is an effective protection against outsourcing. Thus, Brown et al's story suggests that the real problem is not necessarily convincing the highly mobile worker to stay with their employer (for those in the highest strata of the skills distribution, this might be different, of course). Instead, the problem is how to bind the job to the employee.

It is well known that different kinds of skills are associated with different degrees of asset specificity. In this respect, the one-dimensional view of Brown et al. on education is disappointing, but understandable given the focus on the 
case of the USA. A discussion of the role of vocational education and training would have added an interesting new perspective to the debate. The cooperation between employees-institutionalized through unions-and employers in (some) European coordinated market economies facilitates joint investments in human capital and creates mutual dependencies that offer a form of protection against outsourcing of jobs in the middle segment of the skills distribution. The idea of cross-class cooperation, however, is alien to Anglo-American public discourse, which continues to cultivate class conflict and culture wars.

\section{Outlook: what is to be done?}

Towards the end of the book, Brown et al. propose a 'new opportunity bargain' (p. 154). This final part of the book is quite anticlimactic and, for the most part, pours old wine in new bottles. For example, Brown et al. demand that 'Every effort needs to be made to equip American workers with the skills and support they need to succeed in the global auction' (p. 155), but they do not spell out the concrete measures that should be taken. What kinds of skills need to be developed, and who should pay for the provision of these skills? Furthermore, Brown et al. assert that education should be regarded 'as a freeing of individual capacity linked to social aims not limited to economic advantage' (p. 155). This may be desirable from a moral point of view, but will it help (American) workers to compete in the global economy? In sum, Brown et al's recommendations for a 'new opportunity bargain' are not that different from the traditional policy approaches à la Tony Blair ('Education, education, education'), while in fact the book started out with a sophisticated critique of this kind of oversimplified approach to the problem of globalizing labour markets.

All in all, however, the book is a very important contribution to the debate on skills and inequality. Academics and policy-makers alike will benefit from reading it.

\section{References}

Becker, G. S. (1993) Human Capital: A Theoretical and Empirical Analysis with Special Reference to Education, 3rd edn, Chicago, IL/London, University of Chicago Press.

Boix, C. (1998) Political Parties, Growth and Equality: Conservative and Social Democratic Economic Strategies in the World Economy, Cambridge, Cambridge University Press.

Brown, P., Green, A. and Lauder, H. (eds) (2001) High Skills: Globalization, Competitiveness, and Skill Formation, Oxford/New York, NY, Oxford University Press.

Busemeyer, M. R. (2009) 'Asset specificity, institutional complementarities and the variety of skill regimes in coordinated market economies', Socio-Economic Review, 7, 375-406. 
Busemeyer, M. R. and Iversen, T. (2012) 'Collective Skill Systems, Wage Bargaining, and Labor Market Stratification'. In Busemeyer, M. R. and Trampusch, C. (eds) The Comparative Political Economy of Collective Skill Formation Systems, Oxford/New York, NY, Oxford University Press, pp. 205-233.

Crouch, C., Finegold, D. and Sako, M. (1999) Are Skills the Answer? The Political Economy of Skill Creation in Advanced Industrial Countries, Oxford/New York, NY, Oxford University Press.

Emmenegger, P. (2009) 'Specificity versus replaceability: the relationship between skills and preferences for job security regulations', Socio-Economic Review, 7, 407-430.

Estevez-Abe, M., Iversen, T. and Soskice, D. (2001) 'Social Protection and the Formation of Skills: A Reinterpretation of the Welfare State'. In Hall, P. A. and Soskice, D. (eds) Varieties of Capitalism: The Institutional Foundations of Comparative Advantage, Oxford/New York, NY, Oxford University Press, pp. 145-183.

Goldin, C. and Katz, L. F. (2008) The Race between Education and Technology, Cambridge, MA, Belknap Press.

Hacker, J. S. (2006) The Great Risk Shift: The Assault on American Jobs, Families, Health Care and Retirement_and How You Can Fight Back, Oxford/New York, NY, Oxford University Press.

Hacker, J. S. and Pierson, P. (2010) Winner-Take-All Politics: How Washington Made the Rich Richer-and Turned Its Back on the Middle Class, New York, NY, Simon \& Schuster.

Streeck, W. (2012) 'Skills and Politics: General and Specific'. In Busemeyer, M. R. and Trampusch, C. (eds) The Political Economy of Collective Skill Formation, Oxford/ New York, NY, Oxford University Press, pp. 317-352.

\section{Hal Hansen*}

Independent Scholar, Quincy, MA, USA

*Correspondence: hal_hansen@post.harvard.edu

The Global Auction is a book whose subtitle sums up its central contention: ever more schooling hardly guarantees more and better jobs, either for individuals or society. This provocative claim has troubling implications for several powerful groups, none of which will accept it without a fight. These include: colleges and universities, especially in the USA, which are finding it increasingly difficult to justify rising costs to prospective students, their parents and the various governmental bodies that subsidize them; a proliferating for-profit sector of technical and professional institutes and on-line schools with influential investors on Wall Street, in the national media and elsewhere; policymakers, on the right and the 
left, who have embraced what the authors call 'the opportunity bargain', an educational lifeline that ostensibly offers social justice to anyone willing to work hard and get an education; economists, who have championed the view that technological change has been skill-using since 1900, driving a rising demand for education; and a host of international organizations such as the OECD, UNESCO's European Center for Higher Education and the Council of Europe devoted to the expansion of university systems. These groups espouse investing more in higher education to grow the economy, create employment and enhance the quality and remuneration of work.

Phillip Brown, Hugh Lauder and David Ashton-British educational sociologists-confront this 'vast propaganda machine' and its claim that 'learning equals earning. They do so by means of four empirical observations. First, although most proponents of educational expansion focus on national goals and trends, the authors document a stunning, ongoing global expansion of higher education and the international supply of educated 'high-skill' workers. Their analysis of 113 emerging and developed countries, especially China and India, finds that post-secondary enrollments have nearly doubled from 72.5 to 131.6 million between 1996 and 2007 (p. 35). Further, in comparison with the curricular fare that characterizes higher education in the USA and the UK, much of this expansion, particularly in Asia, has focused on math, science, medicine and engineering. Given the still comparatively low standard of living in these societies, most of their people are willing to work for wages substantially below what their counterparts earn in the USA, Western Europe or Japan.

Second, the authors sketch a 'quality and price revolution'. Through extensive interviews with leading firms in many countries, they report rapidly narrowing quality and productivity gaps between advanced and developing economies in manufacturing and services, altering the way international firms think about workforce strategy. Given the price advantages of locating business activity in emergent high-skill, lower-wage societies or recruiting people from these to relocate elsewhere, they claim it to be increasingly difficult to believe that high-wage societies can maintain their standard of living through 'islands of excellence'. This is particularly difficult for large, diverse countries such as the USA. Consequently, a reverse auction is taking place, one in which wages are bid down as quality is maintained. While they concede that wage gaps are narrowing as developing economies catch-up, they observe that there still is a long way to go.

Moreover, even as wages in developing countries rise, a third trend, what Brown and colleagues term 'Digital Taylorism', pushes back in the other direction, reducing the skill sets requisite for many jobs and depressing wages. While I believe they mischaracterize important parts of Taylorism and industrial history, this is not fatal to their claim that technological innovation and job routinization are downgrading a broad range of white-collar jobs, especially in 
services, where the bulk of the labor force works. Historically, these have been good white-collar employments requiring considerable education and skill, covering a wide range of occupations from customer service reps and technical assistants to bank loan officers and insurance claim adjusters. However, due to advances in software and computational power, many of these jobs are being standardized, simplified and filled by personnel with lower educational levels and wage expectations. Others have been eliminated altogether through sophisticated voice recognition systems, software scripting and automated decision trees. Further, these developments have diffused to previously unaffected professions such as architecture through computer-aided design, the law via data mining and analytics software, and medicine, thanks to computer-aided detection and diagnosis, to name just three.

Fourth and finally, the authors detail an international 'war for talent' focusing on small numbers of elite universities across the globe, a competition particularly intense at American and British institutions. Firms, even large, well-financed multinationals, lack the reach and resources to conduct a global hunt themselves; so they turn to top universities to perform the search and select functions for them. The USA and UK owe their special place in this contest to the number of universities they place atop of the educational hierarchy and to their ability to attract so many of the world's best students. Like the leading firms that recruit from them, these schools compete for 'top talent' themselves since, far more than educating and socializing this elite, they sort and certify it. Naturally, they also expect the recruitment of the 'best and the brightest' to ensure wealthy benefactors and powerful advocates for public support down the road.

Although the authors' exposition would have benefited from a clearer explanation of how this 'war for talent' buttresses their central argument, as I read them, this is two-fold. First, they are deeply chary of the returns-to-education literature, for it fails to differentiate returns all along the post-secondary educational hierarchy. Just as the lion's share of all income gains in the USA over the past 30 years have accrued to high-income earners, they believe graduates of the elite schools garner most of the returns to education, especially as real hourly wages in many college-certified occupations fall. Since the overwhelming majority of scholars use averages in making their returns-to-education calculations, these are subject to the same criticism as studies using income or wealth averages when Warren Buffet is a member of the group.

Second and equally troubling for the 'educational opportunity bargain', access to these institutions is heavily weighted in favour of children from upper and upper middle class backgrounds. In fact, a vast body of research across a number of fields has shown that parental education and resources are powerful predictors of success at school. Moreover, family resources, connections and unusual talents associated with privileged backgrounds facilitate admittance to 
most elite institutions. Thus, instead of offering a relatively fair path of social mobility, top institutions function to reproduce cultural capital and class structure across generations. Meanwhile, the returns to education at the lower end of the college hierarchy, especially within the dubious on-line for-profit sector (where schools routinely spend more on advertising and recruitment than on instruction), are lower and less certain, especially as this sector suffers such high drop-out rates.

Taken together, these contentions build a powerful indictment of the 'vast propaganda machine', urging us to spend ever-increasing sums on higher education as investments in ourselves, our children and the economic health of our societies. But how does their critique hold up?

First, the global expansion of post-secondary schooling is clear-cut and the rate of growth has been accelerating. The authors have surprisingly little to say, however, about the extensive literature on degree inflation, especially in developing nations, a trend highlighted long ago by Ronald Dore in The Diploma Disease (1976). They do address Claudia Goldin and Lawrence Katz's influential contention (2008) that skill-biased technological change has caused rising income inequality, since post-secondary educational growth in the USA has not kept pace with the implied demand for an educated workforce (pp. 126-127). They question Goldin and Katz's returns-to-education data, since the latter through aggregation, mix out large differences in these returns along the educational hierarchy. Disconfirmation, however, will have to await better empirical evidence. Further, the authors emphasize that national studies overlook dramatic global increases in educational supply, a growth driving down wages in a wide range of middle-class occupations. This appears to be happening internationally, not only in the USA and the UK. Most sociological literature has shown labor markets to be preponderantly local (Leicht, 2008), however; so the impact of global educational trends on these are complex and indirect.

Second, the quality-price 'revolution' is hardly revolutionary; it has been part and parcel of capitalist development from the beginning. Economic and other historians have repeatedly documented this phenomenon: the industrious revolution from the sixteenth century, the industrial revolution from the eighteenth century and the second industrial revolution in the twentieth century. Among other things, each involved the discovery of new ways to make useful, dependable products with comparatively unskilled labor. Note that, on balance, this has had less to do with 'deskilling' than with the recruitment of inexperienced or 'unskilled' labor in or from the countryside as the demand for market goods and, thus, non-agricultural labor rose (Hansen, 1997). Consequently, the quality-price 'revolution' that the authors describe is simply a new avatar of a process of long standing. 
Third, 'Digital Taylorism' — essentially the substitution of capital for labor involving a reorganization of work and, thus, occupations - is hard to quantify and its long-range consequences notoriously difficult to predict. The Luddite response to power looms was to destroy them, for they believed mechanization would bring an end to paid employment. Economists, in contrast, see this as part of the secular process of 'creative destruction', a term Schumpeter took from Marx and turned on its head. The authors provide thin empirical evidence for this section of their book, though it is clear that encroaching software and cheap, powerful computing is part of the process placing a long-established middle class on the skids (Skocpol, 2000). In a just published e-book, Race Against The Machine (2011), MIT's Erik Brynjolfsson and Andrew McAfee also contend, with a better statistical base, that artificial intelligence is doing to whitecollar jobs in services what robots have done to blue-collar ones in manufacturing. However, the jury remains out with respect to the global long-range effects on employment, though the immediate outlook is grim.

Fourth, there is little doubt that an international 'war for talent' is intensifying, especially within many of the large multinational firms the authors examined. We know that the entire USA university and college hierarchy has become more stratified over the past three decades, with the top 10\% becoming more selective and privileged while the rest have become less so (Hoxby, 2009). Further, social stratification research has made it clear that widening wage differentials within occupations and social groups have rendered research based on averages, typical of the returns-to-education sort, increasingly irrelevant as fewer and fewer people are represented by the mean (Leicht, 2008). Clearly, we need better, more nuanced returns-to-education studies.

Global Auction is a stimulating book that asks crucial questions. Its polemical undertone, its depiction of industrial history and its often thin but difficult-to-marshal evidence will give some readers pause. Nevertheless, its central arguments are provocative, important and plausible, if not yet fully verified. One gnawing question too often overlooked remains: what are the effects of university systems on the rest of the educational hierarchy and how do these affect the education, occupational choices and life chances of the majority of wage earners who do not earn post-secondary degrees? What about them?

\section{References}

Brynjolfsson, E. and McAfee, A. (2011) Race Against the Machine: How the Digital Revolution is Accelerating Innovation, Driving Productivity, and Irreversibly Transforming Employment and the Economy, Lexington, MA, Digital Frontier Press.

Dore, R. P. (1976) The Diploma Disease: Education, Qualification, and Development, Berkeley, CA, University of California Press. 
Goldin, C. D. and Katz, L. F. (2008) The Race between Education and Technology, Cambridge, MA, Belknap Press of Harvard University Press.

Hansen, H. (1997) Caps and Gowns: Historical Reflections on the Institutions That Shaped Learning for and at Work in Germany and the United States, 1800-1945, Ph.D. Dissertation, Madison, WI, University of Wisconsin.

Hoxby, C. M. (2009) 'College Admissions: The Changing Selectivity of American Colleges', Journal of Economic Perspectives, 23, 95-118.

Leicht, K. T. (2008) 'Broken Down by Race and Gender? Sociological Explanations of New Sources of Earnings Inequality', Annual Review of Sociology, 34, 237-255.

Skocpol, T. (2000) The Missing Middle: Working Families and the Future of American Social Policy, 1st edn, New York, NY, W. W. Norton.

\section{Marino Regini*}

University of Milan, Italy

*Correspondence: marino.regini@unimi.it

This is one of those books that is rather easy, and also pleasant, to read. It has very clear arguments, endlessly repeated in slightly different formulations; few hard data, dispersed in an overall discursive framework; and themes very relevant to everyday life and everybody's experience, rather than being limited to narrow topics that can only be illuminated through technically complex analyses.

It would be difficult to be in major disagreement with the book's overall argument. The neo-liberal 'opportunity bargain' has failed to deliver on the promise of education, jobs and economic rewards. We were led to believe that, in our knowledge economies, the value of education would continue to rise and that educated workers would be sheltered from price competition, but this belief has proved false for a series of reasons that are discussed at length in the book. There has been a dramatic discrepancy between the rhetoric of endless upward mobility and a much gloomier reality, which calls not just for explanations, but also for the regulation of global capitalism. One could go on illustrating how this basic argument is developed in several directions, sometimes brilliantly, as the authors present an impressive array of stories, episodes and examples that give the 'flesh' needed to understand what otherwise abstract trends mean for the lives of real people.

Yet, several aspects of the general architecture of the book are rather unsatisfactory. I shall mention four such aspects, though given space constraints, I shall elaborate on the last one only.

The first of these aspects is the sharp contrast between the powerful, challenging and often convincing arguments presented to the reader and the poor 
methodology used to support or test those arguments. We are offered almost exclusively the anecdotal evidence to which I have just referred, which consists mainly of statements by a diverse set of actors chosen more or less at random. The authors make no systematic attempt to demonstrate the existence of relationships between the trends they describe and the factors they select as relevant. The 'cutting edge research based on a major international study' — to which the book's flyer refers - actually seems much more similar to a journalistic report collecting a series of informal conversations with people occupying important roles, and which is intended to strike the reader's attention more than to draw up an accurate and rigorous assessment of the phenomena under discussion.

The second unsatisfactory aspect is the almost complete lack of differentiation among advanced economies. Indeed, even in the terminology used by the authors, it is never entirely clear whether they want to describe trends typical of American society (or at most of American and British societies), or of all the advanced Western economies. The language they use throughout the book-the 'American' labour force, families, college graduates, middle classes, all faced with the challenges raised by the Asian developing countries-would speak in favour of the former hypothesis. But the authors quite often extend their discourse to Britain, and occasionally to other advanced countries such as France, Germany, Japan and Australia, as if these were mere appendices to the same processes. Even if one does not subscribe to any theory of Varieties of Capitalism or to any typology of welfare regimes, it cannot be ignored that several of the trends described by the authors take rather different forms in different political economies. For instance, in regard to the nexus between education, jobs and incomes, which is the core of the book, it is not possible simply to ignore the debate on the 'Nordic model'. One can well argue against its actual specificity or its sustainability in the face of increasing trends towards convergence, but one cannot overlook the role of different institutional contexts in producing different outcomes.

This is an especially awkward failure for a book that, especially in its concluding chapter, strongly advocates a greater role for the state and political institutions vis-à-vis the dominant free-market ideology held responsible for most of the problems described by the authors. The alternative solutions that the authors themselves outline in these conclusions, however, constitute the third unsatisfactory aspect. As one reads the book, expectation grows for the authors to discuss the 'new opportunity bargain based on an alternative political economy of hope' (p. 148). But this discussion is rather fuzzy, and it does not take us much further than the 'democratic conversation about new priorities that link economic activity to the quality of life' advocated by the authors (p. 154).

The last aspect that I find rather unsatisfactory is, however, the one on which I would like to dwell a little longer. It concerns the constant conflation of-and 
frequent confusion among - the factors that the authors consider responsible for the failure of the 'American dream'. These factors concern different processes, which are described at length and mostly in a convincing manner, but which should always be kept analytically distinct because each of them does not have just a different impact on this failure, but also a different chance of finding a solution to its negative consequences.

One such factor is the over-supply of educated knowledge workers as a result of what Martin Trow (1974) already some 40 years ago called the 'generalized access' to higher education in the USA and other advanced economies. A second factor is the globalization of the human capital market and the outsourcing of knowledge jobs: namely, the 'global auction' for bargain brainpower to which the book's title alludes, made possible by the impressive expansion of higher education and investment in research in the developing countries of Asia. A third factor does not concern the supply side, but rather the deep changes in demand: what the authors call the rise of 'digital Taylorism', which 'involves translating the knowledge work of managers, professionals and technicians into working knowledge by capturing, codifying and digitalizing their work in software packages, templates and prescripts that can be transferred and manipulated by others regardless of location' (p. 72).

The internal dynamics, the actors involved and the consequences of each of these factors are to some extent discussed separately in the book. But to a much larger extent, they are treated as components of a general syndrome and are therefore used (especially the first two factors) somewhat interchangeably. This makes it more difficult to assess the impact of each factor and the chances of finding solutions to their negative consequences.

That 'generalized access' to higher education would eventually lead to a mismatch between demand and supply even in the most advanced, knowledgeintensive economies is an old prediction. The survey data collected in several countries do not provide conclusive evidence in this regard. My argument here, however, is different. The authors blame the oversupply of graduates on what is usually called a 'skill-biased technological view' of economic growth, which finds its main proponents among human capital theorists (Becker, 2006) and its main support in the naïve belief that knowledge economies will require an increase in a number of highly skilled professionals. This 'credentials inflation' is alleged to be the consequence of a narrow-minded view of education as economic investment and of the related idea that 'learning is earning'. However, if this were the whole story, we should see much more growth in the rates of enrolment in the vocational tracks of tertiary education (which are closer to labour market actors) than in the academic ones. This has not been the case, however. As shown by the recent OECD (2011) report, in the past 15 years, the matriculation rate into 'tertiary-type A' (academic) education has increased by $25 \%$, 
reaching a record level of 59\% of young adults in the OECD countries, while the matriculation rate into 'tertiary-type B' (shorter and largely vocational) programmes by young adults has remained stable at the far lower level of $19 \%$. This means that the expansion of higher education has been driven far more by a competition for social status than by a narrow-minded view of education as economic investment.

However, regulating a competition for status is different-and far more difficult-than fighting a skill-biased technological view of economic growth. Among other things, it involves creating a complex system of rewards for a wide set of functions that higher education institutions can perform, which is at odds with the dominant emphasis on 'excellence' and with the one-dimensional culture of university rankings as if they were football league tables.

The second factor, which represents a sort of leitmotiv in the book, is the globalization of the human capital market and the outsourcing of knowledge jobs. Actually, this is the theme in support of which the authors provide the largest and most convincing pieces of evidence, however scattered and unsystematic. A sort of 'global auction' for highly-skilled but low-paid jobs, made possible especially by the impressive expansion of higher education and investment in research in the developing Asian countries, emerges vividly as a powerful trend from the several individual stories recounted in the book.

Pointing to the perverse effects of a globalization of the human capital market without a corresponding internationalization of market regulation is not a new idea either, but the authors' discussion shows how these effects are much more far-reaching than is commonly assumed. The optimist's answer to this challenge is usually that in the long run it will produce a win-win solution, as consumers in emerging markets begin to demand better quality products and services, and the larger developing economies will provide new opportunities for the knowledge workers in the advanced economies that in the short term are bound to suffer from this competition. The authors convincingly show that this will not be the inevitable outcome (besides the fact that 'we are all dead in the long run').

The possible solutions to this problem, however, seem to lie in a realm entirely different from the one where we must search when reacting to the first factor, the over-supply of educated knowledge workers. The challenge here is not to regulate the competition for status and to shape the structure of our higher education systems in more intelligent ways. Rather, the challenge is to impose labour and welfare standards as a conditio sine qua non for free trade. This has to do, not with national visions on the multiple functions of education, but with international visions of a world order in which market forces must be regulated as much as they are at the national level in order to avoid a backlash.

The last, and possibly most interesting, factor highlighted by the authors is what they call 'digital Taylorism': an attempt by companies to reduce the cost 
of knowledge work through a process of knowledge capture. On reading the description of how new technologies are leading to the 'standardization of an increasing proportion of technical, managerial and professional jobs', one is reminded of Braverman's (1974) view of the degradation of work during the past century and of the endless debates in the '70s and ' 80 s between 'pessimists' and 'optimists'. The only way out of those debates was empirical research conducted by sociologists of work which eventually showed how the reality of Fordist-Taylorist systems of production was far more complex and nuanced than assumed by either the pessimists or the optimists. No less importantly, the fieldwork conducted by industrial relations scholars showed that the mass production regime had important unintended consequences, as the advent of the 'mass worker' favoured collective action, and that the internal contradictions of mass production eventually led to its abandonment in favour of other systems.

One of the most positive effects of this book would be precisely to encourage a new wave of empirical research that would help us give better definition to the actual features of the new world described in this book.

\section{References}

Becker, G. S. (2006) 'The Age of Human Capital'. In Lauder, H., Brown, P., Dillabough, J.-A. and Halsey, A. H. (eds) Education, Globalization, and Social Change, Oxford/New York, NY, Oxford University Press, pp. 292-294.

Braverman, H. (1974) Labor and Monopoly Capital: The Degradation of Work in the Twentieth Century, New York, NY/London, Monthly Review Press.

OECD (2011) Education at a Glance 2011: OECD Indicators, Paris, OECD Publishing.

Trow, M. (1974) 'Problems in the Transition from Elite to Mass Higher Education'. In OECD (ed) Policies for Higher Education, Paris, OECD, pp. 51-101. 